\title{
Regional economic forecasting: state-of-the-art methodology and future challenges
}

\author{
Robert Lehmann* • Klaus Wohlrabe \\ Ifo Institute - Leibniz-Institute for Economic Research at the University of Munich, Germany
}

Received: 9 September 2014

Revised: 15 December 2014

Accepted: 5 January 2015

\begin{abstract}
Over the last decade, the topic of regional economic forecasting has become increasingly prevalent in academic literature. The most striking problem in this context is data availability at a regional level. However, considerable methodological improvements have been made to address this problem. This paper summarises a multitude of articles from academic journals and describes state-of-the-art techniques in regional economic forecasting. After identifying current practices, the article closes with a roadmap for possible future research activities.
\end{abstract}

Keywords: regional economic forecasting, regional gross-domestic product, regional labour markets

JEL Classification Codes: E27, E37, R23, R11

\section{Scope and aim of this article}

Data unavailability, low data publication frequency and substantial data revisions are the most striking problems facing regional economic forecasting. These barriers can prevent academics from conducting more intensive studies of regional economic forecasting compared to that of national aggregates. However, there is a fast-growing body of literature that is tackling these issues by, for example, applying new methodologies especially developed for regional purposes.

The scope of this brief survey article is to present state-of-the-art methodology in regional economic forecasting. It concentrates on two specific macroeconomic aggregates: (i) total output such as gross domestic product (GDP) or gross value added (GVA) and (ii) labour market variables like total employment or the unemployment rate. It is important to note that forecasting literature on other regional variables like revenues or housing prices already

\footnotetext{
* Corresponding author. E-mail: lehmann@ifo.de.

Citation: Lehmann, R. and Wohlrabe, K. (2014) Regional economic forecasting: state-of-the-art methodology and future challenges, Economics and Business Letters, 3(4), 218-231.
} 
exists. However, this article does not focus on these issues. After presenting the findings of existing studies, we outline key areas for future research in the field of regional economic forecasting.

\section{State-of-the-art in regional economic forecasting}

In order to summarise existing literature on this topic, the articles in question must be classified. In addition to the region and the target variable that each study focuses on, Table 1 presents five main features of such articles. Firstly, we name the data frequency that the forecasting exercise is based on. Secondly, we identify the methodology that is used in each study. Thirdly, to understand the purpose of the forecast, we indicate the forecasting horizon. Fourthly, we give a statement on the forecasting performance of the methods applied in each single study. Finally, we identify potential areas for future research, whenever they are named in the specific study. These five specifics constitute the scope and aim of this article. All of the studies in Table 1 are ordered anti-chronologically. The results from Table 1 can be summarised as follows:

1. Most of the studies focus on regional labour market forecasting. Studies for GDP or GVA tend to be scarce. However, thanks to new methodological approaches (e.g. spatial panel data models), the strand of literature focusing on GDP or GVA developed rapidly in the 2010s.

2. The Data frequency column reveals that no monthly output variables have been used as a target variable. This might be due to the fact that industrial production, for example, which is often used at a national level, is not available at a monthly frequency for regional units. For labour market analyses, monthly indicators are even available in very small regions. From a time series perspective, this is a huge advantage in comparison to output variables.

3. The labour studies show a higher regional disaggregation than the studies with output variables. Whereas many labour market studies focus on smaller regions below the state level, nearly all output studies are conducted for rather large regional entities. One prominent exception is the study by Baltagi et al. (2014), which uses data from the NUTS-2 level.

4. To mitigate the problem of a data scarce environment, spatial panel data models are becoming increasingly common practice in regional forecasting. Many authors explicitly mention the necessity of spatial effects to capture, for example, regional spillovers (Baltagi et al., 2014). In this context, the study by Mayor and Patuelli (2012) is worth mentioning. They explicitly examine the trade-off between the cross section and time dimension. The main message from their exercise is that time series models work better than spatial models when the time dimension is higher than the cross section. In cases where the two dimensions nearly equal each other, spatial models outperform more sophisticated time series models. Additionally, Rapach and Strauss (2012) emphasise the outstanding role of labour market data in studying such methodological differences. In this way, future regional economic forecasting literature may be able to improve forecasting performance by simply applying models that are designed for different cross section and time dimension setups.

5. Factor models and forecast combinations tend to be scarce in literature on this topic. However, since data sets have become even larger in the recent past, existing studies clearly state the benefits of large data set methods for regional economic forecasting.

6. Nearly all studies apply parametric methods by postulating a linear relationship between the target variable and the independent variables. This has, among others, 
been criticised by Patuelli et al. (2008) or Blien and Tassinopoulos (2001) since academic literature on the topic has not yet reached a consensus on regional economic interdependencies or linkages. The studies mention that non-linear models clearly show forecast improvements and are a good competitor to standard techniques. Additionally, only a handful of papers apply structural models. Most of the existing literature prevents the application of structural models due to data scarcity.

7. Most of the studies compare their methodology with benchmark models such as the univariate autoregressive process by using standard accuracy measures (e.g., root mean squared forecast errors). However, only a handful of articles offer statements about the statistical significance of forecast error differences (e.g., Lehmann and Wohlrabe, 2015, 2014 or Kopoin et al., 2013).

8. All of the papers present point forecasts. Up to this date and to the best of our knowledge, no studies featuring density or interval forecasts at a regional level exist. Additionally, most of the papers evaluate one single point forecast of a different method with the ex post realisation of the specific variable. The paper by Mayor et al. (2007) is one exception: this study provides different scenarios and discusses the role of a scenario analysis for regional economic forecasting.

9. Most of the studies focus on either the short term (one year ahead) or calculate medium term (up to three years ahead) forecasts. However, there are studies that produce forecasts ranging from five (Kholodilin et al., 2008) up to fifteen (Girardin and Kholodilin, 2011) or even twenty years (Polasek et al., 2007). ${ }^{1}$

10. The bulk of studies concerning labour market variables are conducted for the U.S. The opposite holds for studies with output target variables. Here, to the best of our knowledge, most of the existing literature focuses on Germany or Europe.

Academic improvements in regional forecasting, however, do not tell us anything about their practical relevance. Since regional economic forecasting has become increasingly attractive within the last ten years, it has also gained practical relevance over this time period. The following examples are aimed at emphasising the role of regional economic forecasting in practice. The Ifo Institute, Dresden Branch (Ifo), as well as the Halle Institute for Economic Research (IWH), provide regional economic forecasts for Germany. As mentioned by Blien and Tassinopoulos (2001), the Institute for Employment Research (IAB) provides regional labour market forecasts for the Federal Employment Agency in Germany. The Simon Center for Regional Economic Forecasting prepares forecasts for the metropolitan St. Louis area and the State of Missouri. The Economic Forecasting Project by the Old Dominion University and the REMI (Regional Economic Models, Inc.) are other prominent representatives.

To develop a roadmap for the practical use of these forecasts, we draw attention to which builds upon our literature review. In future research it can be rearranged or complemented.

Figure 1. Data frequency and preferable methods

\footnotetext{
${ }^{1}$ To clarify our wording, we have to define the different forecasting ranges used. These definitions should not be mixed up with the wording in standard macroeconomics. In our setup, the short term comprises all studies with a forecast horizon up to one year. Additionally, short term forecasts should not be mixed up with Nowcasts, which focus on an "ultra" short forecast horizon (e.g. the current and following quarter). Medium term forecasts are produced for horizons of up to three years. All papers that concentrate on forecasts with a horizon longer than three years are classified as long term.
} 


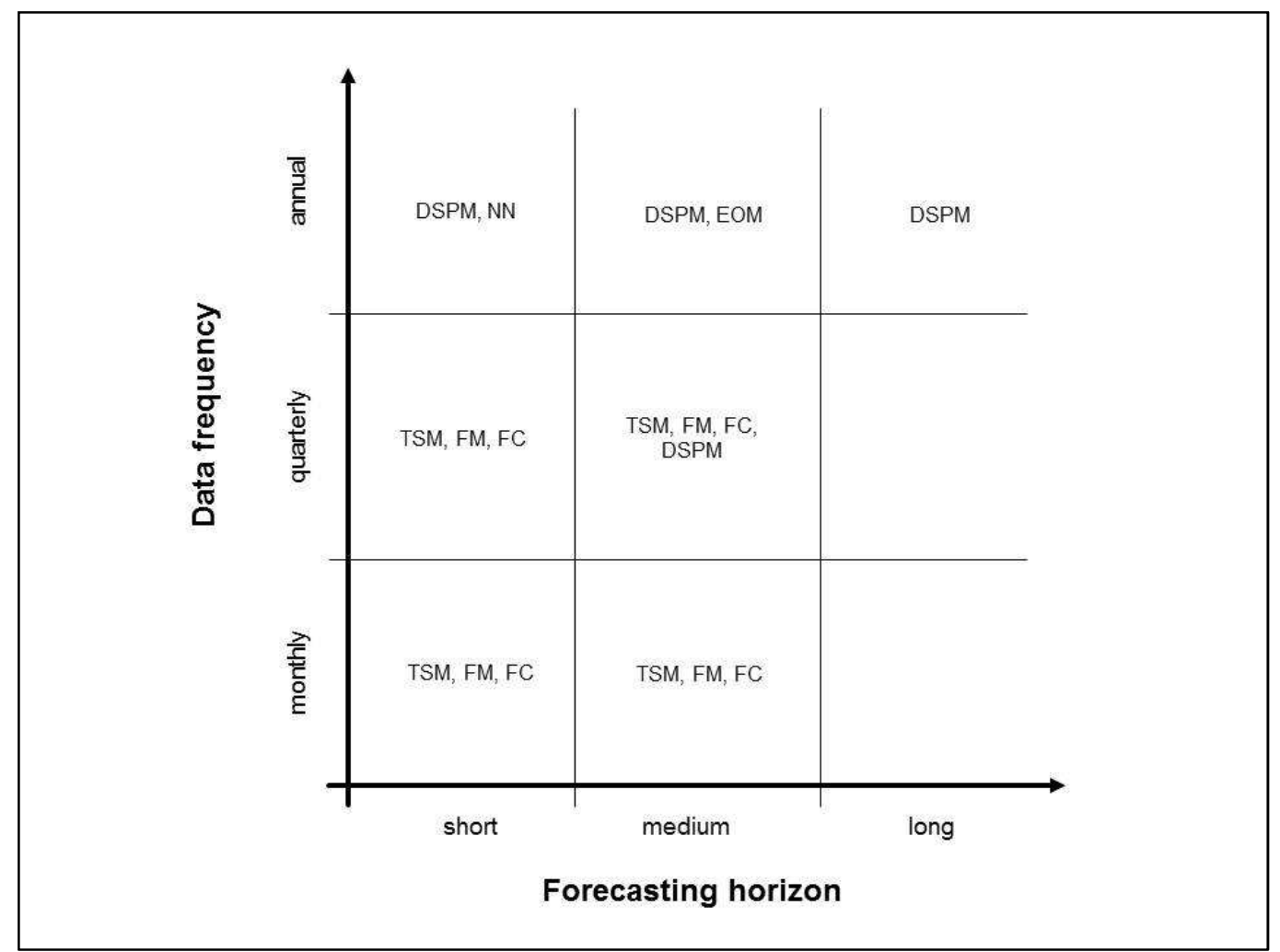

Note: DSPM: dynamic spatial panel data models, EOM: entropy-optimizing method, FC: forecast combination, FM: factor models, NN: neural network models, TSM: time series models

Figure 1 clearly demonstrates that a practical forecast based on annual data should incorporate spatial effects, or make use of more uncommon methods like neural networks. Turning to the other extreme, monthly data, time series models or methods based on large data sets can improve forecasting accuracy. The same holds for quarterly data. However, forecasting accuracy with spatial effects and monthly data has not been tested yet. Additionally, studies with monthly or quarterly data do not evaluate their models for longer horizons. Since most of the studies focus on point forecasts, literature on different scenario analyses is scarce. Based on this state-of-the-art discussion, we now turn to the agenda for future research.

\section{A roadmap for future research}

This short discussion of state-of-the-art methodology has shown that regional economic forecasting is a constantly evolving field in academic literature and has grown increasingly attractive within the last decade. This is not surprising since regional policy-makers have to rely on unbiased regional economic forecasts. However, there is still a great deal of room left for improvement. In this section, we discuss potential topics that should be addressed in future research activities. As in the section before, we summarise possible research activities as follows:

- Dynamic spatial panel data models should be applied to quarterly instead of annual GDP data in order to capture business cycle effects more accurately. From our point of view, this can only be done by using quarterly information. Since quarterly information is almost not available for regional GDP, future research could apply disaggregation methods as in Wenzel and Wolf (2013). Additionally, the studies by Lehmann and Wohlrabe $(2015,2014)$ use quarterly information that is provided by 
other researchers. The methods for disaggregation are used by the European Commission and can be easily applied to regional data.

- Sticking again to the discussion of spatial effects, we have no clear evidence of the forecasting accuracy of these models for GDP or GVA in smaller regions like cities, rural districts or counties. To date, we have only evidence for states (see, for example, Kholodilin et al., 2008). For Germany, there are GDP data available on an annual basis for all free cities and counties. Such research activities can further develop the discussion started by Mayor and Patuelli (2012), which mentions the trade-off between the cross section and time dimension.

- To date, there is only little evidence of how regional forecast errors are distributed over the business cycle. Future research should concentrate on the question of how well the methods are suited to forecasting different phases of the business cycle. The great economic downturn of the years 2008/2009 in particular yield criticism on standard methods at the national level. However, detecting turning points is a major task not only for regional economic forecasts, but also for their national counterparts.

- Another methodological application is the consideration of indicators from different regional entities. At a regional level, we could ask whether we can generate more accurate forecasts if we incorporate information from the national or even international level. Different trade patterns or high heterogeneity in regional economic structures in particular justify such an analysis.

- As put forward by Blien and Tassinopoulos (2001), it is absolutely necessary to understand economic linkages at a regional level in greater detail, and to use this knowledge to create unbiased forecasts. In a better data environment, this could easily be achieved by using structural models. Since it is nearly impossible to generate these data, especially for macroeconomic aggregates like GDP or consumption, techniques such as the ENTROP method or non-linear models should be studied more intensively and compared to standard methods.

- Following on from the previous point, we consider whether linear models are preferable to their non-linear counterparts. The existing studies only evaluate nonlinear techniques for specific years and regions. Future research activities should evaluate this question over time and for different regional entities.

- From a general point of view, no "meta-study" exists that compares different forecasting methods. All of the existing studies compare accuracy to that of standard benchmark models. However, the methods coexist with each other and we have found no evidence of which works best for different situations (business cycle phases, tradeoff between time and cross section dimension etc.). The study by West and Fullerton (1996) states that different regions are more predictable than others. Yet what are the reasons for these differences?

- In addition to the previous point, future research should analyse regional economic forecasting for another set of countries. The studies mentioned in this paper only focus on eight different countries. Most of the literature, in turn, analyses either Germany or the US. Whenever there is a need for forecasts by a huge amount of different countryspecific policy-makers, future research should replicate papers for different countries.

- The studies by Lehmann and Wohlrabe $(2015,2014)$ show that large data set methods such as forecast combinations are able to produce more accurate forecasts in comparison to standard univariate models. However, another way of dealing with large data sets are Bayesian Vector Autoregressions (BVAR). To the best of our knowledge, this approach has only been adopted by Puri and Soydemir (2000) or Dua and Miller (1996). 
- We further emphasise the application of methods that are intensively discussed at the national level like, for example, methods based on mixed frequencies (e.g., MIDAS or bridge equations), boosting algorithms or time-varying parameters (TVP).

- The real time aspect of economic forecasting is neglected by almost all studies. It is not only that the papers do not explicitly account for publication lags (pseudo real time analysis), revisions of regional economic variables are only studied by Coomes (1992). However, this paper only focuses on regional labour market figures. As is clearly mentioned by Coomes (1992), revisions at the regional level have a higher magnitude than at the national level. This could cause significant forecast errors.

- A potential research area is the aggregation of different forecasts. One issue raised in Lehmann and Wohlrabe (2014) is whether the aggregation of sectoral forecasts leads to lower forecast errors compared to a direct forecast of the aggregate (e.g., sectoral GVA vs. total GVA) at a regional level. Such an analysis can easily be conducted for labour market variables, where nearly all of the data are available. This research question can also be combined with a discussion of spatial effects.

- Another avenue of research is to ask whether the aggregation of regional economic forecasts leads to lower forecasting errors of the national aggregate. As an example we use the economic development of Germany. Germany consists of 16 different states. The question is: what is the most accurate way to forecast total German GDP? There are two possibilities: (i) a direct forecast of German GDP, or (ii), a prediction based on an aggregation of forecasts for each of the 16 single states. The second approach may lead to lower forecasts errors since it accounts for region-specific developments.

- In the end, we stick to the purpose of regional economic forecasting. Most of the studies focus on point forecasts. However, regional policy-makers are potentially interested in density (or interval) forecasts, or a scenario analysis, rather than in standard point estimates. Future research should discuss how all of the methods available are able to address this question.

Huge advances have been made in regional economic forecasting over the last decade, as shown by this discussion of state-of-the-art methodology. However, there is still a great deal of room left for future research on this topic and we emphasise the need to devote more attention to several of the points already raised in academic literature and listed above.

Acknowledgements. We would like to thank an anonymous referee for fruitful comments and suggestions on this manuscript. We are also grateful to Matías Mayor, Roberto Patuelli and Michael Weber for their careful reading; and to Lisa Giani Contini for editing this text. 
Table 1. Overview of regional economic forecasting studies

\begin{tabular}{|c|c|c|c|c|c|c|c|}
\hline Study & Region & Target variable & $\begin{array}{c}\text { Data } \\
\text { frequency }\end{array}$ & Methodology & Forecast horizon & $\begin{array}{c}\text { Forecast } \\
\text { performance }\end{array}$ & Future Research \\
\hline $\begin{array}{l}\text { Lehmann and } \\
\text { Wohlrabe (2015) }\end{array}$ & $\begin{array}{l}\text { GER: two states } \\
\text { (NUTS-1, Saxony and } \\
\text { Baden-Württemberg) } \\
\text { and } \\
\text { Eastern Germany }\end{array}$ & GDP, total & quarterly & $\begin{array}{l}\text { time series models, } \\
\text { forecast combination, } \\
\text { factor models }\end{array}$ & $\begin{array}{l}\text { point forecasts with } \\
\text { horizon one up to four } \\
\text { quarters ahead }\end{array}$ & $\begin{array}{l}\text { forecast combination } \\
\text { with best results in } \\
\text { comparison to } \\
\text { standard univariate } \\
\text { benchmark model }\end{array}$ & $\begin{array}{l}\text { to use time series } \\
\text { models, yearly data } \\
\text { are disaggregated to } \\
\text { quarterly } \\
\text { information } \\
\text { large data set } \\
\text { methods }\end{array}$ \\
\hline Baltagi et al. (2014) & $\begin{array}{l}\text { Europe: } 255 \text { NUTS-2 } \\
\text { regions }\end{array}$ & GVA per worker, total & annual & $\begin{array}{l}\text { dynamic spatial panel } \\
\text { data models }\end{array}$ & $\begin{array}{l}\text { point forecasts with } \\
\text { horizon one and two } \\
\text { years ahead }\end{array}$ & $\begin{array}{l}\text { better ex post } \\
\text { performance in } \\
\text { comparison to } \\
\text { standard spatial and } \\
\text { non-spatial } \\
\text { estimators } \\
\end{array}$ & $\begin{array}{l}\text { spatial models } \\
\text { absolutely } \\
\text { necessary to capture } \\
\text { regional spillovers }\end{array}$ \\
\hline $\begin{array}{l}\text { Lehmann and } \\
\text { Wohlrabe (2014) }\end{array}$ & $\begin{array}{l}\text { GER: one state } \\
\text { (NUTS-1, Saxony) }\end{array}$ & GVA, total and sectoral & quarterly & $\begin{array}{l}\text { time series models, } \\
\text { forecast combination, } \\
\text { factor models }\end{array}$ & $\begin{array}{l}\text { point forecasts with } \\
\text { horizon one up to four } \\
\text { quarters ahead }\end{array}$ & $\begin{array}{l}\text { forecast combination } \\
\text { with best results in } \\
\text { comparison to } \\
\text { standard univariate } \\
\text { benchmark model } \\
\text { sectoral } \\
\text { disaggregated } \\
\text { forecasts better in the } \\
\text { short run }\end{array}$ & $\begin{array}{l}\text { to use time series } \\
\text { models, yearly data } \\
\text { are disaggregated to } \\
\text { quarterly } \\
\text { information } \\
\text { sectoral } \\
\text { disaggregation } \\
\text { large data set } \\
\text { methods }\end{array}$ \\
\hline Kopoin et al. (2013) & $\begin{array}{l}\text { CAN: two provinces } \\
\text { (Quebec and Ontario) }\end{array}$ & GDP, total & quarterly & factor models & $\begin{array}{l}\text { point forecasts with } \\
\text { horizon one up to } \\
\text { twelve quarters ahead }\end{array}$ & $\begin{array}{l}\text { international and } \\
\text { national indicator } \\
\text { have predictive } \\
\text { information in the } \\
\text { short run (one year } \\
\text { ahead); afterwards } \\
\text { only regional } \\
\text { information matter }\end{array}$ & $\begin{array}{l}\text { international, } \\
\text { national and } \\
\text { regional } \\
\text { information for the } \\
\text { exercise } \\
\text { large data set } \\
\text { methods }\end{array}$ \\
\hline Wenzel (2013) & $\begin{array}{l}\text { GER: all German states } \\
\text { (NUTS-1) }\end{array}$ & GDP, total & annual & panel data models & $\begin{array}{l}\text { point forecasts with } \\
\text { horizon one and two } \\
\text { years ahead }\end{array}$ & $\begin{array}{l}\text { regional business } \\
\text { survey data produce } \\
\text { lower forecasts } \\
\text { errors for one year } \\
\text { ahead forecasts }\end{array}$ & -- \\
\hline
\end{tabular}




\begin{tabular}{|c|c|c|c|c|c|c|c|}
\hline $\begin{array}{l}\text { Wenzel and Wolf } \\
\text { (2013) }\end{array}$ & $\begin{array}{l}\text { GER: four German } \\
\text { states (NUTS-1, } \\
\text { Bremen, Hamburg, } \\
\text { Lower Saxony and } \\
\text { Schleswig-Holstein }\end{array}$ & GDP, total & quarterly & time series models & $\begin{array}{l}\text { point forecasts with } \\
\text { horizon one up to } \\
\text { three quarters ahead }\end{array}$ & $\begin{array}{l}\text { business survey data } \\
\text { outperform } \\
\text { univariate } \\
\text { benchmark model }\end{array}$ & $\begin{array}{l}\text { to use time series } \\
\text { models, yearly data } \\
\text { are disaggregated to } \\
\text { quarterly } \\
\text { information }\end{array}$ \\
\hline $\begin{array}{l}\text { Mayor and Patuelli } \\
\text { (2012) }\end{array}$ & $\begin{array}{l}\text { CH: all Swiss cantons } \\
\text { (NUTS-3); ESP: all } \\
\text { provinces (NUTS-3) }\end{array}$ & unemployment rate & $\begin{array}{l}\mathrm{CH} \text { : } \\
\text { monthly; } \\
\text { ESP: } \\
\text { quarterly }\end{array}$ & $\begin{array}{l}\text { spatial panel data models } \\
\text { and SVAR }\end{array}$ & $\begin{array}{l}\text { point forecasts with } \\
\text { horizon one up to } \\
\text { twenty-four months } \\
\text { ahead (Switzerland) or } \\
\text { one up to eight } \\
\text { quarters ahead (Spain) }\end{array}$ & $\begin{array}{l}\text { performance of each } \\
\text { method depends } \\
\text { highly on the data } \\
\text { frequency; SVAR } \\
\text { better in } \\
\text { Switzerland; spatial } \\
\text { models with more } \\
\text { accuracy in Spain }\end{array}$ & $\begin{array}{l}\text { data frequency very } \\
\text { important for the } \\
\text { usage of methods } \\
\text { future literature } \\
\text { should focus on the } \\
\text { trade-off between } \\
\text { the cross-section } \\
\text { and time dimension, } \\
\text { especially for long } \\
\text { term forecasts }\end{array}$ \\
\hline $\begin{array}{l}\text { Rapach and Strauss } \\
\text { (2012) }\end{array}$ & USA: all federal states & employment, total & quarterly & $\begin{array}{l}\text { time series models, } \\
\text { forecast combination, } \\
\text { factor models }\end{array}$ & $\begin{array}{l}\text { point forecasts } \\
\text { combination with } \\
\text { horizon two and four } \\
\text { quarters ahead }\end{array}$ & $\begin{array}{l}\text { all model classes } \\
\text { better than the } \\
\text { univariate } \\
\text { benchmark model } \\
\text { combination } \\
\text { strategies work well } \\
\text { for all states, } \\
\text { especially in } \\
\text { recessions }\end{array}$ & $\begin{array}{l}\text { labor market data } \\
\text { perfectly suited to } \\
\text { study the different } \\
\text { methodological } \\
\text { approaches (time } \\
\text { series vs. panel } \\
\text { data) } \\
\text { generalization of } \\
\text { the results }\end{array}$ \\
\hline $\begin{array}{l}\text { Girardin and } \\
\text { Kholodilin (2011) }\end{array}$ & CHN: all provinces & GDP, total & annual & spatial panel data models & $\begin{array}{l}\text { point forecasts with } \\
\text { horizon one up to } \\
\text { fifteen years ahead }\end{array}$ & $\begin{array}{l}\text { higher forecast } \\
\text { accuracy with spatial } \\
\text { effects (in } \\
\text { comparison to a } \\
\text { standard univariate } \\
\text { benchmark model } \\
\text { and standard panel } \\
\text { data models) } \\
\text { for very long } \\
\text { horizons, a large } \\
\text { improvement with } \\
\text { spatial effects is } \\
\text { observable }\end{array}$ & $\begin{array}{l}\text { only few studies } \\
\text { which focus on } \\
\text { GDP and spatial } \\
\text { effects } \\
\text { especially for long } \\
\text { term forecasts, } \\
\text { spatial effects } \\
\text { should be included }\end{array}$ \\
\hline
\end{tabular}




\begin{tabular}{|c|c|c|c|c|c|c|c|}
\hline Schanne et al. (2010) & $\begin{array}{l}\text { GER: all labor market } \\
\text { regions }\end{array}$ & unemployment & monthly & univariate spatial GVAR & $\begin{array}{l}\text { point forecasts with } \\
\text { horizon one up to } \\
\text { twelve months ahead }\end{array}$ & $\begin{array}{l}\text { GVAR performs } \\
\text { better than the } \\
\text { univariate } \\
\text { benchmark model } \\
\text { spatial effects show a } \\
\text { large improvement } \\
\text { for longer horizons }\end{array}$ & $\begin{array}{l}\text { results highly } \\
\text { depend on the } \\
\text { model specification } \\
\text { and the specific } \\
\text { region }\end{array}$ \\
\hline $\begin{array}{l}\text { Kholodilin et al. } \\
(2008)\end{array}$ & $\begin{array}{l}\text { GER: all German states } \\
\text { (NUTS-1) }\end{array}$ & GDP, total & annual & $\begin{array}{l}\text { dynamic spatial panel } \\
\text { data models }\end{array}$ & $\begin{array}{l}\text { point forecasts with } \\
\text { horizon one up to five } \\
\text { years ahead }\end{array}$ & $\begin{array}{l}\text { higher forecast } \\
\text { accuracy with spatial } \\
\text { models in } \\
\text { comparison to } \\
\text { standard panel } \\
\text { models (again: large } \\
\text { improvement in the } \\
\text { long run) }\end{array}$ & -- \\
\hline Patuelli et al. (2008) & $\begin{array}{l}\text { GER: all labor market } \\
\text { regions }\end{array}$ & employment, total & annual & $\begin{array}{l}\text { neural network models, } \\
\text { genetic algorithms }\end{array}$ & $\begin{array}{l}\text { point forecast for one } \\
\text { single year }\end{array}$ & $\begin{array}{l}\text { neural network } \\
\text { models with good } \\
\text { performance, better } \\
\text { in comparison to a } \\
\text { random walk }\end{array}$ & $\begin{array}{l}\text { introduction of non- } \\
\text { linear models }\end{array}$ \\
\hline $\begin{array}{l}\text { Dreger and Kholodilin } \\
(2007)\end{array}$ & $\begin{array}{l}\text { GER: one state } \\
\text { (NUTS-1, Berlin) }\end{array}$ & GDP, total & quarterly & static factor models & $\begin{array}{l}\text { point forecasts with } \\
\text { horizon one up to } \\
\text { eight quarters ahead }\end{array}$ & $\begin{array}{l}\text { significant in-sample } \\
\text { improvement }\end{array}$ & -- \\
\hline $\begin{array}{l}\text { Longhi and Nijkamp } \\
\text { (2007) }\end{array}$ & $\begin{array}{l}\text { GER: labor market } \\
\text { regions in Western } \\
\text { Germany }\end{array}$ & employment, total & annual & $\begin{array}{l}\text { static non-spatial and } \\
\text { spatial panel data models }\end{array}$ & $\begin{array}{l}\text { point forecasts for } \\
\text { three single years }\end{array}$ & $\begin{array}{l}\text { forecast } \\
\text { improvement in } \\
\text { comparison to a } \\
\text { naïve benchmark } \\
\text { model } \\
\end{array}$ & $\begin{array}{l}\text { results highly } \\
\text { depend on the } \\
\text { model specification } \\
\text { and the specific } \\
\text { region }\end{array}$ \\
\hline Patuelli et al. (2007) & $\begin{array}{l}\text { GER: all districts } \\
\text { (NUTS-3) }\end{array}$ & employment, total & annual & $\begin{array}{l}\text { neural network models, } \\
\text { Friedman statistic }\end{array}$ & $\begin{array}{l}\text { point forecasts for } \\
\text { three single years }\end{array}$ & $\begin{array}{l}\text { neural network } \\
\text { models are able to } \\
\text { forecast the ranking } \\
\text { of regional units }\end{array}$ & $\begin{array}{l}\text { introduction of non- } \\
\text { linear models }\end{array}$ \\
\hline Polasek et al. (2007) & AUS: regions & $\begin{array}{l}\text { GDP and employment, } \\
\text { total }\end{array}$ & annual & $\begin{array}{l}\text { dynamic spatial panel } \\
\text { data models }\end{array}$ & $\begin{array}{l}\text { point forecasts up to } \\
\text { twenty years ahead }\end{array}$ & $\begin{array}{l}\text { no evidence on } \\
\text { performance }\end{array}$ & -- \\
\hline Mayor et al. (2007) & $\begin{array}{l}\text { ESP: one autonomous } \\
\text { community (Asturias, } \\
\text { NUTS-2) }\end{array}$ & $\begin{array}{l}\text { employment, total and } \\
\text { sectoral }\end{array}$ & quarterly & $\begin{array}{l}\text { dynamic Shift-share- } \\
\text { techniques in } \\
\text { combination with time } \\
\text { series models }\end{array}$ & $\begin{array}{l}\text { point forecasts one- } \\
\text { step ahead for three } \\
\text { different years }\end{array}$ & $\begin{array}{l}\text { dynamic models } \\
\text { with the best } \\
\text { forecasting } \\
\text { performance }\end{array}$ & $\begin{array}{l}\text { discussion on } \\
\text { forecasting and } \\
\text { scenario analyses } \\
\text { comparison of shift- } \\
\text { share techniques } \\
\text { with standard } \\
\text { methods }\end{array}$ \\
\hline
\end{tabular}




\begin{tabular}{|c|c|c|c|c|c|c|c|}
\hline Longhi et al. (2005) & $\begin{array}{l}\text { GER: all labor market } \\
\text { regions in Western } \\
\text { Germany }\end{array}$ & employment, total & annual & $\begin{array}{l}\text { artificial neural network } \\
\text { models, panel data } \\
\text { models, forecast } \\
\text { combinations }\end{array}$ & $\begin{array}{l}\text { point forecast for one } \\
\text { single year }\end{array}$ & $\begin{array}{l}\text { artificial neural } \\
\text { network model with } \\
\text { best performance in } \\
\text { comparison to a } \\
\text { naïve no-change } \\
\text { forecast }\end{array}$ & $\begin{array}{l}\text { introduction of non- } \\
\text { linear models } \\
\text { test on whether the } \\
\text { performance holds } \\
\text { over time }\end{array}$ \\
\hline $\begin{array}{l}\text { Rapach and Strauss } \\
\text { (2005) }\end{array}$ & $\begin{array}{l}\text { USA: one federal state } \\
\text { (Missouri) }\end{array}$ & employment, total & monthly & $\begin{array}{l}\text { time series models, } \\
\text { combination, } \\
\text { factor models }\end{array}$ & $\begin{array}{l}\text { point forecasts for } \\
\text { three, six, twelve and } \\
\text { twenty-four months } \\
\text { ahead }\end{array}$ & $\begin{array}{l}\text { forecast combination } \\
\text { methods outperform } \\
\text { the standard } \\
\text { univariate } \\
\text { benchmark model }\end{array}$ & -- \\
\hline $\begin{array}{l}\text { Bandholz and Funke } \\
\text { (2003) }\end{array}$ & $\begin{array}{l}\text { GER: one state } \\
\text { (NUTS-1, Hamburg) }\end{array}$ & GDP, total & quarterly & $\begin{array}{l}\text { leading indicator based } \\
\text { on a dynamic factor } \\
\text { model }\end{array}$ & -- & $\begin{array}{l}\text { business cycle dating } \\
\text { and development of } \\
\text { regional leading } \\
\text { indicator }\end{array}$ & $\begin{array}{l}\text { usage of leading } \\
\text { indicators to date } \\
\text { regional business } \\
\text { cycle } \\
\text { important for } \\
\text { forecasters to } \\
\text { predict turning } \\
\text { points }\end{array}$ \\
\hline Megna and Xu (2003) & $\begin{array}{l}\text { USA: one federal state } \\
\text { (New York) }\end{array}$ & coincident index & monthly & $\begin{array}{l}\text { leading indicator based } \\
\text { on a dynamic factor } \\
\text { model }\end{array}$ & $\begin{array}{l}\text { point forecasts with } \\
\text { horizon up to twelve } \\
\text { months }\end{array}$ & $\begin{array}{l}\text { leading indicator is } \\
\text { able to predict } \\
\text { regional recessions }\end{array}$ & - \\
\hline $\begin{array}{l}\text { Blien and } \\
\text { Tassinopoulos (2001) }\end{array}$ & $\begin{array}{l}\text { GER: all districts } \\
\text { (NUTS-3) in Western } \\
\text { Germany }\end{array}$ & employment, total & annual & $\begin{array}{l}\text { entropy-optimizing } \\
\text { procedure (ENTROP) }\end{array}$ & $\begin{array}{l}\text { point forecast for the } \\
\text { year } 1999 \text { ( } 2 \text { years } \\
\text { ahead) }\end{array}$ & $\begin{array}{l}\text { ENTROP method } \\
\text { shows improvements } \\
\text { over standard } \\
\text { methods }\end{array}$ & $\begin{array}{l}\text { method is able to } \\
\text { reproduce regional } \\
\text { linkages and } \\
\text { causations }\end{array}$ \\
\hline & & & & & & & $\begin{array}{l}\text { forecasts are used } \\
\text { by the Federal } \\
\text { Employment } \\
\text { Agency in Germany }\end{array}$ \\
\hline $\begin{array}{l}\text { Puri and Soydemir } \\
(2000)\end{array}$ & $\begin{array}{l}\text { USA: counties in } \\
\text { Southern California }\end{array}$ & employment, industrial & quarterly & time series models & $\begin{array}{l}\text { point forecasts with } \\
\text { horizon up to four } \\
\text { quarters ahead }\end{array}$ & $\begin{array}{l}\text { BVAR best model; } \\
\text { other time series } \\
\text { models outperform } \\
\text { the naïve benchmark }\end{array}$ & -- \\
\hline Shoesmith (2000) & USA: all federal states & $\begin{array}{l}\text { employment, non- } \\
\text { agricultural }\end{array}$ & monthly & $\begin{array}{l}\text { time series models with } \\
\text { composite leading } \\
\text { indicators }\end{array}$ & $\begin{array}{l}\text { point forecasts for } \\
\text { one, three, six, nine } \\
\text { and twelve months } \\
\text { ahead }\end{array}$ & $\begin{array}{l}\text { national indicator } \\
\text { with higher forecast } \\
\text { accuracy than the } \\
\text { regional indicator }\end{array}$ & -- \\
\hline $\begin{array}{l}\text { Trívez and Mur } \\
\text { (1999) }\end{array}$ & $\begin{array}{l}\text { ESP: one autonomous } \\
\text { community (Aragón, } \\
\text { NUTS-2) }\end{array}$ & employment, sectoral & quarterly & time series models & $\begin{array}{l}\text { point forecasts for the } \\
\text { four quarters of one } \\
\text { specific year }\end{array}$ & $\begin{array}{l}\text { transfer functions } \\
\text { outperform the } \\
\text { ARIMA benchmark }\end{array}$ & -- \\
\hline
\end{tabular}




\begin{tabular}{|c|c|c|c|c|c|c|c|}
\hline Miller (1998) & $\begin{array}{l}\text { USA: one federal state } \\
\text { (Idaho) and related } \\
\text { sub-regions }\end{array}$ & employment, total & monthly & time series models & $\begin{array}{l}\text { point forecasts for the } \\
\text { twelve months of one } \\
\text { specific year }\end{array}$ & $\begin{array}{l}\text { state-level forecasts } \\
\text { produce lower } \\
\text { forecast errors than } \\
\text { sub-state-level } \\
\text { forecasts }\end{array}$ & -- \\
\hline Dua and Miller (1996) & $\begin{array}{l}\text { USA: one federal state } \\
\text { (Connecticut) }\end{array}$ & $\begin{array}{l}\text { employment (coincident } \\
\text { index), non-farm } \\
\text { employment, } \\
\text { unemployment rate }\end{array}$ & monthly & $\begin{array}{l}\text { time series models based } \\
\text { on leading indicator }\end{array}$ & $\begin{array}{l}\text { point forecasts for one } \\
\text { up to six months } \\
\text { ahead (three different } \\
\text { time periods) }\end{array}$ & $\begin{array}{l}\text { BVAR dominates } \\
\text { simple VAR model, } \\
\text { both outperform the } \\
\text { univariate } \\
\text { benchmark }\end{array}$ & -- \\
\hline $\begin{array}{l}\text { West and Fullerton } \\
\text { (1996) }\end{array}$ & $\begin{array}{l}\text { USA: metropolitan } \\
\text { areas in federal state } \\
\text { (Florida) }\end{array}$ & employment, total & quarterly & $\begin{array}{l}\text { time series and structural } \\
\text { models }\end{array}$ & $\begin{array}{l}\text { point forecasts for } \\
\text { horizon one up to ten } \\
\text { quarters ahead }\end{array}$ & $\begin{array}{l}\text { structural models not } \\
\text { worse than time } \\
\text { series models; both } \\
\text { outperform the } \\
\text { historical average as } \\
\text { benchmark }\end{array}$ & $\begin{array}{l}\text { meta study to } \\
\text { discuss the } \\
\text { accuracy of } \\
\text { different methods }\end{array}$ \\
\hline $\begin{array}{l}\text { Holmes and } \\
\text { Shamsuddin (1993) }\end{array}$ & $\begin{array}{l}\text { CAN: one province } \\
\text { (British Columbia) }\end{array}$ & employment, industrial & monthly & $\begin{array}{l}\text { time series models with } \\
\text { leading indicators based } \\
\text { on different methods }\end{array}$ & $\begin{array}{l}\text { point forecasts with } \\
\text { horizon one up to } \\
\text { twelve months ahead }\end{array}$ & $\begin{array}{l}\text { models with leading } \\
\text { indicator outperform } \\
\text { ARIMA benchmark }\end{array}$ & -- \\
\hline Coomes (1992) & $\begin{array}{l}\text { USA: one federal state } \\
\text { (Virginia) and one } \\
\text { statistical area } \\
\text { (Louisville) }\end{array}$ & job estimates, sectoral & monthly & Kalman filtering & -- & $\begin{array}{l}\text { practical relevance to } \\
\text { incorporate revisions } \\
\text { into economic } \\
\text { forecasts }\end{array}$ & $\begin{array}{l}\text { studying revisions } \\
\text { at a regional level }\end{array}$ \\
\hline LeSage (1990) & $\begin{array}{l}\text { USA: metropolitan } \\
\text { areas in federal state } \\
\text { (Ohio) }\end{array}$ & employment, total & monthly & time series models & $\begin{array}{l}\text { point forecasts with } \\
\text { horizon of one up to } \\
\text { twelve months ahead }\end{array}$ & $\begin{array}{l}\text { error correction } \\
\text { models with best } \\
\text { performance }\end{array}$ & $\begin{array}{l}\text { error correction } \\
\text { models especially } \\
\text { useful to model } \\
\text { long run } \\
\text { relationships and } \\
\text { short term } \\
\text { fluctuations }\end{array}$ \\
\hline Weller (1989) & $\begin{array}{l}\text { USA: one metropolitan } \\
\text { statistical area (Erie) }\end{array}$ & employment, total & monthly & time series models & $\begin{array}{l}\text { point forecasts with } \\
\text { horizon one up to } \\
\text { twelve months ahead, } \\
\text { calculated for two } \\
\text { specific years }\end{array}$ & $\begin{array}{l}\text { univariate } \\
\text { benchmark is } \\
\text { outperformed }\end{array}$ & $\begin{array}{l}\text { data unavailability } \\
\text { prevents the } \\
\text { estimation of } \\
\text { regional structural } \\
\text { models } \\
\end{array}$ \\
\hline $\begin{array}{l}\text { Weller and Kurre } \\
\text { (1989) }\end{array}$ & $\begin{array}{l}\text { USA: one metropolitan } \\
\text { statistical area (Erie) }\end{array}$ & $\begin{array}{l}\text { employment, total and } \\
\text { sectoral }\end{array}$ & monthly & $\begin{array}{l}\text { time series models and } \\
\text { shift-share techniques }\end{array}$ & $\begin{array}{l}\text { point forecasts for } \\
\text { each of the twelve } \\
\text { months of } 1984\end{array}$ & $\begin{array}{l}\text { incorporation of } \\
\text { shift-share } \\
\text { techniques leads to } \\
\text { lower forecast errors }\end{array}$ & -- \\
\hline
\end{tabular}




\begin{tabular}{|c|c|c|c|c|c|c|c|}
\hline Glennon et al. (1987) & $\begin{array}{l}\text { USA: one statistical } \\
\text { area (Louisville) }\end{array}$ & employment, sectoral & quarterly & $\begin{array}{l}\text { time series and structural } \\
\text { models }\end{array}$ & no clear description & $\begin{array}{l}\text { univariate models } \\
\text { with best } \\
\text { performance in } \\
\text { comparison to } \\
\text { structural models }\end{array}$ & $\begin{array}{l}\text { structural models at } \\
\text { the regional level } \\
\text { can be used for } \\
\text { scenario analyses }\end{array}$ \\
\hline $\begin{array}{l}\text { Weller and Kurre } \\
\text { (1987) }\end{array}$ & $\begin{array}{l}\text { USA: one metropolitan } \\
\text { statistical area (Erie) }\end{array}$ & employment, total & quarterly & time series models & $\begin{array}{l}\text { point forecasts with } \\
\text { horizon one up to four } \\
\text { quarters ahead }\end{array}$ & $\begin{array}{l}\text { transfer functions } \\
\text { improve regional } \\
\text { forecast }\end{array}$ & -- \\
\hline Thirlwall (1975) & $\begin{array}{l}\text { UK: government office } \\
\text { regions (NUTS-1) }\end{array}$ & $\begin{array}{l}\text { unemployment rate, } \\
\text { vacancies }\end{array}$ & quarterly & time series models & $\begin{array}{l}\text { point forecasts for the } \\
\text { year } 1973\end{array}$ & -- & -- \\
\hline
\end{tabular}

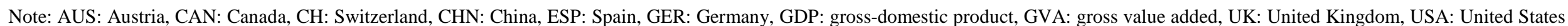
of America. 


\section{References}

Baltagi, B.H., Fingleton, B. and Pirotte, A. (2014) Estimating and forecasting with a dynamic spatial panel data model, Oxford Bulletin of Economics and Statistics, 76(1), 112-138.

Bandholz, H. and Funke, M. (2003) Die Konstruktion und Schätzung eines Konjunkturfrühindikators für Hamburg, Wirtschaftsdienst, 83(8), 540-548.

Blien, U. and Tassinopoulos, A. (2001) Forecasting regional employment with the ENTROP method, Regional Studies, 32(2), 113-124.

Coomes, P.A. (1992) A Kalman filter formulation for noisy regional job data, International Journal of Forecasting, 7(4), 473-481.

Dreger, C. and Kholodilin, K.A. (2007) Prognosen der regionalen Wirtschaftsentwicklung, Vierteljahreshefte zur Wirtschaftsforschung, 76(4), 47-55.

Dua, P. and Miller, S.M. (1996) Forecasting and analyzing economic activity with coincident and leading indexes: the case of Connecticut, Journal of Forecasting, 15(7), 509-526.

Girardin, E. and Kholodilin, K.A. (2011) How helpful are spatial effects in forecasting the growth of Chinese provinces? Journal of Forecasting, 30(7), 622-643.

Glennon, D., Lane, J. and Johnson, S. (1987) Regional econometric models that reflect labor market relations, International Journal of Forecasting, 3(2), 299-312.

Holmes, R.A. and Shamsuddin, A.F.M. (1993) Evaluation of alternative leading indicators of British Columbia industrial employment, International Journal of Forecasting, 9(1), 77-83.

Kholodilin, K.A., Kooths, S. and Siliverstovs, B. (2008) A dynamic panel data approach to the forecasting of the GDP of German Länder, Spatial Economic Analysis, 3(2), 195207.

Kopoin, A., Moran, K. and Paré, J.P. (2013) Forecasting regional GDP with factor models: How useful are national and international data? Economics Letters, 121(2), 267-270.

Lehmann, R. and Wohlrabe, K. (2015) Forecasting GDP at the regional level with many predictors, German Economic Review, forthcoming, DOI: 10.1111/geer.12042.

Lehmann, R. and Wohlrabe, K. (2014) Forecasting gross value-added at the regional level: Are sectoral disaggregated predictions superior to direct ones? Review of Regional Research: Jahrbuch für Regionalwissenschaft, 34(1), 61-90.

LeSage, J.P. (1990) Forecasting metropolitan employment using an export-base errorcorrection model, Journal of Regional Science, 30(3), 307-323.

Longhi, S. and Nijkamp, P. (2007) Forecasting regional labor market developments under spatial autocorrelation, International Regional Science Review, 30(2), 100-119.

Longhi, S., Nijkamp, P., Reggiani, A. and Maierhofer, E. (2005) Neural network modeling as a tool for forecasting regional employment patterns, International Regional Science Review, 28(3), 330-346.

Mayor, M. and Patuelli, R. (2012) Short-run regional forecasts: spatial models through varying cross-sectional and temporal dimensions, in Fernandez-Vazquez, E. and Rubiera-Morollón, F. (eds) Defining the spatial scale in modern regional analysis: new challenges from data at the local level, Springer-Verlag Berlin Heidelberg, Ch. 9, 173192.

Mayor, M., López, A.J. and Pérez, R. (2007) Forecasting regional employment with shiftshare and ARIMA modelling, Regional Studies, 41(4), 543-551.

Megna, R. and Xu, Q. (2003) Forecasting the New York state economy: the coincident and leading indicators approach, International Journal of Forecasting, 19(4), 701-713.

Miller, J.R. (1998) Spatial aggregation and regional economic forecasting, The Annals of Regional Science, 32(2), 253-266. 
Patuelli, R., Longhi, S., Nijkamp, P., Reggiani, A. and Blien, U. (2007) A rank-order test on the statistical performance of neural network models for regional labor market forecasts, The Review of Regional Studies, 37(1), 64-81.

Patuelli, R., Longhi, S., Nijkamp, P. and Reggiani, A. (2008) Neural networks and genetic algorithms as forecasting tools: a case study on German regions, Environment and Planning B: Planning and Design, 35(4), 701-722.

Polasek, W., Sellner, R. and Schwarzbauer, W. (2007) Long term regional forecasting with spatial equation systems, RCEA Working Paper series WP 10-07, Rimini, RN.

Puri, A. and Soydemir, G. (2000) Forecasting industrial employment figures in Southern California: A Bayesian vector autoregressive model, The Annals of Regional Science, 34(4), 503-514.

Rapach, D.E. and Strauss, J.K. (2005) Forecasting employment growth in Missouri with many potentially relevant predictors: an analysis of forecast combining methods, Federal Reserve Bank of St. Louis: Regional Economic Development, 1(1), 97-112.

Rapach, D.E. and Strauss, J.K. (2012) Forecasting US state-level employment growth: an amalgamation approach, International Journal of Forecasting, 28(2), 315-327.

Schanne, N., Wappler, R. and Weyh, A. (2010) Regional unemployment forecasts with spatial interdependencies, International Journal of Forecasting, 26(4), 908-926.

Shoesmith, G.L. (2000) The time-series relatedness of state and national indexes of leading indicators and implications for regional forecasting, International Regional Science Review, 23(3), 281-299.

Thirlwall, A.P. (1975) Forecasting regional unemployment in Great Britain, Regional Science and Urban Economics, 5(3), 357-374.

Trívez, F.J. and Mur, J. (1999) A short-term forecasting model for sectoral regional employment, The Annals of Regional Science, 33(1), 69-91.

Weller, B.R. (1989) National indicator series as quantitative predictors of small region monthly employment levels, International Journal of Forecasting, 5(2), 241-247.

Weller, B.R. and Kurre, J.A. (1987) Applicability of the transfer function approach to forecasting employment levels in small regions, The Annals of Regional Science, 21(1), 34-43.

Weller, B.R. and Kurre, J.A. (1989) Forecasting the local economy, using time-series and shift-share techniques, Environment and Planning A, 21(6), 753-770.

Wenzel, L. (2013) Forecasting regional growth in Germany: a panel approach using business survey data, HWWI Research Paper 133, Hamburg, DE.

Wenzel, L. and Wolf, A. (2013) Short-term forecasting with business surveys: evidence for German IHK data at federal state level, HWWI Research Paper 140, Hamburg, DE.

West, C.T. and Fullerton, T.M. (1996) Assessing the historical accuracy of regional economic forecasts, Journal of Forecasting, 15(1), 19-36. 